\title{
Assessing English Writing through Formative Assessment in EFL Classroom
}

\begin{abstract}
This appraisal intended to investigate the assessment techniques used by an instructor in studying understudies' making capacities, the clarification in executing the systems, and the understudies' responses toward the execution of the strategies. The assembled data in this evaluation included examination corridor discernment that had been held in different occasions, meet, and created report. Coming up next is the goals subject to the data examination. Since formative examination of making capacity is the rule point of convergence of this appraisal, the instructor executed five creating execution endeavors proposed by Brown (2010) explicitly dicto-comp, picture-flagged task, short answer task, coordinated request and answer, and area improvement task. From the appearance collaboration done by the educator, the assessment tasks were executed for formative purposes, that is, to separate understudies' progression getting a handle on the activity that is about account text. The instructor did some assessment tasks in an easygoing way to screen understudies' ceaseless progression without recording the result of the show, while various tasks were executed in an appropriate way to record understudies' headway and to give them an evaluation of their progression and achievement.
\end{abstract}

Keywords: English writing, Formative assessment, EFL students

\section{Introduction}

In informational setting, assessment and showing measure are vague. As suggested by Jabbarifar, assessment revolves around various pieces of teaching and getting, including specific course books and instructive materials, understudy achievement, and whole program direction. A couple of experts consider assessment a central piece of educating and learning. Pellegrino, for instance, prescribe that assessment is expected to screen understudies' disposition and accumulate information to arrive at a target assurance about understudies' data. Various scientists support the possibility that examination is useful for teachers to change the appearance systems and strategies as long as it is dealt with sensibly. Various instructors moreover acknowledge that examination is a basic instrument in advancing understudies move their endeavor in getting, making understudies sure about their last assessment and handiness of contribution to overhauling understudies' show.

Despite the uncommonly significant pieces of examination, it can't be ignored that instructors to a great extent face inconveniences in assessing understudies' making capacity. Since language capacities join four viewpoints (tuning in, talking, examining, and making) and this heap of capacities composed to one another, instructors need to put extra energy in arranging and 
controlling the evaluation techniques. As communicated by Brown (2010) that "the blend of capacities is of imperative importance in language learning".

Besides, if understudies are not locked in with the examination connection, it infers that the assessment isn't completed to its full sufficiency. Along these lines, O' Farrell (2004) suggests that in making examination arrangements, instructors need to zero in on the observable space of understudies' activity, make specific learning results, and assess reasonably. In case the examination isn't arranged true to form, it may reveal essentially zero progress and cripple understudies. Pellegrino et al. (2001) even adds that fruitful teachers need to use changed kinds of assessment similarly as to give contribution on understudies' headway. Furthermore, instructors need to design an evaluation plan enough and gainfully to get a real result of understudies' progression recorded as a printed copy ability and to give analysis in improving understudies' display. Different experts had been coordinated examinations concerning Formative assessment or creating ability. Some of them drove packs in the space of homeroom assessment, and impression of evaluation. Those previous evaluations are according to the accompanying. Jabbarifar (2009) drove an evaluation which was relied upon to look at the meaning of homeroom examination and appraisal benefits similarly as to present some important examination and evaluation techniques which can help language teachers to make dynamic investigation corridor condition for evaluation. Ramadani (2014) moreover guided an evaluation to explore the examination strategies used by teachers in reviewing understudies' talking aptitude. Another evaluation came from Ndalichako (2015) which investigated observations that teachers have in the examination that are presumably going to affect their assessment practices. Mussawy (2009) moreover tried to explore pre-organization teachers' impression of study lobby examination and the representatives' perspective on homeroom assessment similarly as their presumptions for understudies' learning.

Yet a couple of appraisals concerning the assessment association have been driven, it is still shortfall of studies concerning the examination techniques about formative evaluation recorded as a printed copy ability. Subsequently, this examination hopes to fill the opening by separating formative assessment recorded as a printed copy capacities. Also, this appraisal plans to reveal the teacher's defense doing the methods similarly as the understudies' responses of the execution of the techniques. By coordinating this appraisal, it will be revealed whether the teacher used changed sorts of assessment and whether the examination is executed to its full reasonability. 


\section{Methodology}

This evaluation was coordinated by an emotional investigation plan as this examination attempted to portray the evaluation strategies used by a teacher in studying understudies' language capacities. Abstract investigation, as communicated by Creswell (2014), insinuates "a technique for examining and understanding the importance individuals or get-togethers quality to a social or human issue". According to Denzin and Lincoln, emotional evaluation is fitting to use in light of the fact that it tries to think about things in their ordinary settings, to sort out, or unravel, ponders the extent that the ramifications people bring to them (in Creswell, 2013).

\section{Investigation Site and Participants}

This appraisal was driven in a center school. There are two reasons why the school was picked as the setting for this evaluation. Most importantly, the instructor in that school had the option to do the investigation. Second, the school was picked for its openness since the authority of the school allowed the investigator to coordinate the appraisal around then, at that point. Meanwhile, the individuals drew in with this appraisal were an English instructor and a class of tenth grade of center school understudies.

The techniques used are study lobby discernment, meet, and made chronicle. This is as per Klenke (2016) who acknowledges that "various instruments are routinely used to assemble data for logical investigations, including interviews, usage of recorded data or files, or part insight". The detail pattern of data combination will be portrayed under.

\section{Study corridor Observation}

The chief instrument used to react to the investigation question was study lobby discernment. According to Cowie, "Discernment is the insightful seeing and point by point evaluation of individuals' lead in a naturalistic setting". Insight consistently shows up as two ideal sorts including part and non-part. The kind of discernment drove in this examination was non-part insight, where the researcher saw without sharing and separated from the marvel. To help the researcher with seeing all the homeroom practices and to complete the information, video recording was used in this evaluation. It's anything but's a rich source since it got all of the things happened or emerged during the investigation corridor discernment. The data of study corridor insight that was recorded on the video recorder was changed over to video record. The expert drove the insight in a class of tenth grade. There were three observational visits for 100 minutes (2 learning hours) in each visit. The observational visits were intended to discover what kind of 
assessment systems used by the instructor in reviewing understudies' forming ability. It was seen through instructor understudies' association and the whole investigation lobby development.

\section{Conclusion}

Considering the discernment, the endeavors did by the educator were facilitated with each other to achieve the essential objective of the activity, that is, understudies can create a record story by their own words solely. Regardless, the results of the evaluation portrayed a couple of occasions of examination task that intricate making execution. Therefore, the educator completed dictocomp in the principle get-together to familiarize understudies for certain story messages. Short answer task close by coordinated request and answer were executed to check understudies' comprehension of the works and whether they acclimatized the information well. Then, the picture provoked assignment was executed in the resulting social occasion to obtain the understudies' income in learning the customary development of record text by giving pieces of funnies. By coordinating the picture flagged task, the instructor had the alternative to give them a preparation on the most capable technique to take apart ordinary plans and language features of the record text. At last, area improvement task was completed to check understudies' individual capacity recorded as a printed version a record story.

\section{References}

Albana, H. H., Marzuki, A. G., Alek, A., \& Hidayat, D. N. (2020). Cohesive Devices in Student's Writing (A Discourse Analysis on Argumentative Text). Jurnal Pendidikan Humaniora, 8(1), 6-11.

Alek, A., Marzuki, A. G., Farkhan, M., \& Deni, R. (2020). Self-Assessment in Exploring EFL Young learners' Speaking Skill. Al-Ta lim Journal, 27(2), 208-214.

Alek, A., Marzuki, A. G., Farkhan, M., Surahman, D., Daryanto, D., \& Febrianto, S. (2020). Computer Based Testing in Senior High School on National Assessment. Indonesian Journal of Learning Education and Counseling, 2(2), 204-210. Angeles: University of California.

Belanger, J. (2004). 'When Will We Ever Learn?': The Case for Formative Assessment Supporting Writing Development. English in Australia, (141), 41.

Brown, H. D. (2010). Language Assessment: Principles and Classroom Practices (Second Edi). New York: Pearson Education Inc.

Burner, T. (2016). Formative assessment of writing in English as a foreign language. Scandinavian Journal of Educational Research, 60(6), 626-648.

Burner, T. (2016). Formative assessment of writing in English: A school-based study of perceptions, practices and transformations. 
Chappuis, S., Stiggins, R., Arter, J., \& Chappuis, J. (2004). Assessment for Learning. Portland: Assessment Training Institute.

Fatimah, A. S., Santiana, S., \& Saputra, Y. (2019). Digital Comic: An Innovation of Using Toondoo As Media Technology for Teaching English Short Story. English Review: Journal of English Education, 7(2), 101-108.

Frey, N., \& Fisher, D. (2013). A formative assessment system for writing improvement. English Journal, 66-71.

Furtak, E. M., \& Ruiz-Primo, M. A. (2008). Making students' thinking explicit in writing and discussion: An analysis of formative assessment prompts. Science Education, 92(5), 799824.

Garrison, C., Ehringhaus, M. (2013). Formative and Summative Assessments in the Classroom. Association for Middle Level Education. Retrieved from https://www.amle.org/BrowsebyTopic/WhatsNew/WNDet/TabId/270/ ArtMID/888/ArticleID/286/Formative-and-Summative-Assessmentsin-theClassroom.aspx

Graham, S., Harris, K., \& Hebert, M. A. (2011). Informing writing: The benefits of formative assessment. A Carnegie Corporation Time to Act report. LI RESEARCH ARCHIVES ONLINE.

Graham, S., Hebert, M., \& Harris, K. R. (2015). Formative assessment and writing: A metaanalysis. The Elementary School Journal, 115(4), 523-547.

Horstmanshof, L., \& Brownie, S. (2013). A scaffolded approach to discussion board use for formative assessment of academic writing skills. Assessment \& Evaluation in Higher Education, 38(1), 61-73.

Keen, J. (2005). Assessment for writing development: Trainee English teachers' understanding of formative assessment. Teacher Development, 9(2), 237-253.

Klute, Mary. (2017). Formative assessment and elementary school student academic achievement: A review of the evidence. U.S. Department of EducationR EL 2017-259

Korkmaz, S., \& Öz, H. (2021). Using Kahoot to Improve Reading Comprehension of English as a Foreign Language Learners. International Online Journal of Education and Teaching, 8(2), 1138-1150.

Kuliahana, A., \& Marzuki, A. G. (2020). Repetition Technique in an EFL Speaking Class in Islamic Higher Education in Indonesia. Academic Journal Perspective: Education, Language, and Literature, 8(1), 20-28.

Landauer, T. K., Lochbaum, K. E., \& Dooley, S. (2009). A new formative assessment technology for reading and writing. Theory into Practice, 48(1), 44-52.

Lee, I. (2011). Formative assessment in EFL writing: An exploratory case study. Changing English, 18(1), 99-111.

Marzuki, A. G. (2019). The Implementation of SQ3R Method to Develop Learners' Reading Skill on Islamic Texts in EFL Class in Indonesia. Register Journal, 12(1), 49-61. 
Marzuki, A. G. (2019). Utilizing Recorded English Dialogues in Teaching English Word Stress to Islamic Higher Education Learners in Indonesia. Jurnal Pendidikan Islam, 5(1), 53-64.

Marzuki, A. G., Alim, N., \& Wekke, I. S. (2018). Improving the reading comprehension through cognitive reading strategies in language class of coastal area in indonesia. In IOP Conference Series: Earth and Environmental Science, 156(1), 012050). IOP Publishing.

Marzuki, A.G. (2016). Utilizing cooperative learning in islamic college learners' classroom. IJEE (Indonesian Journal of English Education), 3(2), 123-139.

Marzuki, A.G. (2017). Developing speaking skill through oral report in an efl class in indonesia. Al-Ta lim Journal, 24(3), 243-254.

Marzuki, A.G. (2017). Utilizing pictures in increasing learners' vocabulary mastery in an efl class in palu city indonesia. Musawa: Journal for Gender Studies, 9(2), 191-233.

Mohamadi, Z. (2018). Comparative effect of online summative and formative assessment on EFL student writing ability. Studies in Educational Evaluation, 59, 29-40.

Mussawy, S., A., J. (2009). Assessment Practices: Student' s and Teachers 'Perceptions of Classroom Assessment University of Massachusetts School of Education, 1-115.

Reising, B. (1997). The formative assessment of writing. The Clearing House, 71(2), 71-72.

Saeed Alharbi, A., \& Meccawy, Z. (2020). Introducing Socrative as a Tool for Formative Assessment in Saudi EFL Classrooms. Arab World English Journal (AWEJ) Volume, 11.

Santiana, S., \& Fatimah, A. S. (2017). Prezi, Cloud-Based Presentation, for Teaching: How is it Interesting?. EduLite: Journal of English Education, Literature and Culture, 2(2), 445456.

Wragg, E. C. (2003). Assessment and Children's Learning in the Secondary School. London: RoutledgeFalmer.Ndalichako, J. L. (2015). Secondary School Teachers' Perceptions of Assessment. International Journal of Information and Education Technology, 5(5), 326330. https://doi.org/10.7763/IJIET.2015.V5.524 
